\title{
Resistance of the wild tomato Solanum habrochaites to Phytophthora infestans is governed by a major gene and polygenes
}

\author{
MARIANE G.F. COPATI', FLÁVIA M. ALVES ${ }^{1}$, FRANÇOISE D. DARIVA ${ }^{1}$, HERIKA P. PESSOA ${ }^{1}$, \\ FELIPE O. DIAS ${ }^{1}$, PEDRO C.S. CARNEIRO ${ }^{2}$, DERLY J.H. DA SILVA ${ }^{1}$ and CARLOS NICK ${ }^{1}$
}

\author{
${ }^{1}$ Departamento de Fitotecnia, Universidade Federal de Viçosa, Av. P.H. Rolfs, \\ s/n, Campus Universitário, 36570-900 Viçosa, MG, Brazil \\ ${ }^{2}$ Departamento de Biologia Geral, Universidade Federal de Viçosa, Av. P.H. Rolfs, \\ s/n, Campus Universitário, 36570-900 Viçosa, MG, Brazil \\ Manuscript received on February 8, 2019; accepted for publication on April 10, 2019
}

\begin{abstract}
How to cite: COPATI MGF, ALVES FM, DARIVA FD, PESSOA HP, DIAS FO, CARNEIRO PCS, SILVA DJH AND NICK C. 2019. Resistance of the wild tomato Solanum habrochaites to Phytophthora infestans is governed by a major gene and polygenes. An Acad Bras Cienc 91: e20190149. DOI 10.1590/0001-3765201920190149.
\end{abstract}

\begin{abstract}
This work aimed to study the inheritance of resistance to Phytophthora infestans in tomato plants, using the maximum likelihood estimation function. The susceptible cultivar Santa Clara (Solanum lycopersicum) was used as the female genitor and the P. infestans resistant $S$. habrochaites f. glabratum accession (BGH 6902) as the male genitor. $\mathrm{F}_{1}$ plants from the crossing were self-pollinated to produce $\mathrm{F}_{2}$ progenies, and also backcrossed with $\mathrm{P}_{\mathrm{R}}$ and $\mathrm{P}_{\mathrm{S}}$ to produce $\mathrm{BC}_{1: \mathrm{R}}$ and $\mathrm{BC}_{1: \mathrm{S}}$ generations, respectively. The tomato plants were inoculated 50 days after transplanting. Disease severity was evaluated via a diagrammatic scale. Comparison of the genetic models created using the maximum likelihood function revealed that the inheritance of resistance to P. infestans in $S$. habrochaites is conferred by a major gene with additive and dominance effects, polygenes with additive effects, plus the environmental effect. Vertical resistance can be explored using genes with major effects. Programs of recurrent and makerassisted selection are considered efficient strategies with which to select genotypes that hold $P$. infestans resistance conferred by polygenes.
\end{abstract}

Key words: Solanum lycopersicum, Phytophthora infestans, genetic parameters, studies of inheritance, major gene, polygenes.

\section{INTRODUCTION}

Tomato crops are largely recognized for their socioeconomic and nutritional importance worldwide. However, commercial tomato production is subjected to high economic and financial risk, especially considering the large number of diseases that affect tomato plants. Among these diseases,

Correspondence to: Mariane Gonçalves Ferreira Copati

E-mail: marianegonferreira@gmail.com

ORCid: https://orcid.org/0000-0001-7908-5622 the number one concern for tomato growers is late blight, a disease caused by the foliar oomycete Phytophthora infestans (Mont.) de Bary (Duarte et al. 2007).

Management strategies for $P$. infestans in tomato crops often involve the application of large amounts of fungicides. According to economists from the International Potato Center (CIP), around US\$ 1 billion are spent annually to control this disease (Fiorini et al. 2010). However, with the 
emergence of more virulent isolates of the pathogen, that are resistant to existing fungicides, as well as growing concerns regarding environmental safety, the introduction of resistance genes in tomato plants seems to be the most promising pathogencontrol strategy (Park et al. 2005).

Efforts to develop cultivars resistant to $P$. infestans are often the main focus of most prior and current tomato breeding programs. The use of $P$. infestans resistant cultivars/accessions minimizes fungicide application, both reducing costs and making the pathogen management easier, not to mention being a more environmentally friendly alternative. Understanding $P$. infestans resistance gene inheritance mode regarding the expression of a character, therefore, plays an important role in directing breeding program activities and also in achieving genetic gains (Batista et al. 2017).

Research examining the inheritance of resistance to $P$. infestans in tomato plants was carried out by Abreu et al. (2008) based on the methodology of analysis of means proposed by Mather and Jinks (1984) and the minimum number of genes determining the character was estimated using the formula derived from Burton (1951). The authors reported at least 28 genes controlling this trait, suggesting its quantitative inheritance. However, studies involving quantitative traits are very complex when multiple minor-effect genes, highly influenced by environmental conditions, are involved (Li et al. 2011, Baldissera et al. 2014).

Estimation of the number of genes controlling resistance to $P$. infestans made using the above methodology is considered to be of low precision, since it provides information only regarding the number of genes with dominant expression. Moreover, the methodology considers that all genes have equal effects on the phenotypic expression of the character, which may not in fact be the case (Cruz 2012). Therefore, it is necessary to use methodologies that consider the existence of genes with additive and dominant effects, and that are able to distinguish the different effects of each gene on the expression of the selected character.

The methodology proposed by Silva (2003) is an alternative designed to overcome the limitations found in existing studies of genetic inheritance. This methodology considers various hierarchical models ranging from simple models that examine only environmental effects, to more complex models that include the effects of both major genes and polygenes. The aim of the present work was to study the (hypothesized) mixed inheritance of resistance to $P$. infestans in tomato plants using a method based on maximum likelihood estimators (MLEs) to model and estimate parameters related to major genes and polygenes.

\section{MATERIALS AND METHODS}

\section{SITE AND FIELD TRIALS}

Trials were conducted at the Horticulture Research Farm belonging to the Departamento de Fitotecnia da Universidade Federal de Viçosa (UFV), located in Viçosa, MG, Brazil (20 45' 14" S; 42 $2^{\circ} 52^{\prime}$ 53" W; $648.74 \mathrm{~m}$ altitude).

The female genitor $\left(\mathrm{P}_{\mathrm{S}}\right)$ used in the crosses was the susceptible cultivar Santa Clara (Solanum lycopersicum), and the male genitor $\left(\mathrm{P}_{\mathrm{R}}\right)$ was the $P$. infestans resistant accession BGH 6902 (S. habrochaites $f$. glabratum), obtained from the UFV Horticultural Germplasm Bank. Both parents are known to be homozygous at all loci. $\mathrm{F}_{1}$ plants from the crossing were selfed to produce $\mathrm{F}_{2}$ progenies, and also backcrossed with $\mathrm{P}_{\mathrm{R}}$ and $\mathrm{P}_{\mathrm{S}}$ to produce $\mathrm{BC}_{1: \mathrm{R}}$ and $\mathrm{BC}_{1: \mathrm{S}}$ generations, respectively.

The Santa Clara cultivar produces oblong, bi- or tri-locular fruits of around $130 \mathrm{~g}$ in weight that are consumed fresh. In contrast, BGH 6902 accession is a wild tomato accession that produces small, greenish fruits with an unpleasant taste and aroma (Fiorini et al. 2010).

Seedlings were grown in polystyrene trays of 128 cells, each containing Tropstrato substrate (Vida Verde, BRA). Transplantation to the field 
occurred 40 days after sowing when all seedlings showed four to five definitive and fully expanded leaves. Between-row and in-row spacing was 1.0 $\mathrm{m} \times 0.6 \mathrm{~m}$, respectively. Cultivation practices were performed based on crop recommendations. Plants were trellised vertically via a hanging-string system, with water provided by drip irrigation.

\section{PREPARATION OF ISOLATES}

Two days prior inoculation, tomato leaflets containing $P$. infestans isolates known to cause late blight in tomatoes were harvested in three different tomato fields located at the municipalities of Coimbra, Teixeiras and Viçosa in the Zona da Mata region of the Brazilian state of Minas Gerais. Immediately after harvesting, the infected leaflets were placed in plastic trays, previously disinfected with $70 \%$ alcohol and lined with moistened paper towels. The trays were then stored in plastic bags and incubated at $18^{\circ} \mathrm{C}$ for $24 \mathrm{~h}$ to promote sporulation.

\section{INOCULATION OF ISOLATES}

Inoculation involved the use of a mixture containing equal amounts of the three isolate suspensions with concentration adjusted to $10^{3}$ sporangia per milliliter of water by counting in a hemocytometer. The inoculum suspension was then stored in a refrigerator at $4^{\circ} \mathrm{C}$ for about one hour in order to induce the liberation of zoospores.

Inoculation was carried out in the afternoon using a hand-pumped backpack sprayer 50 days after field transplanting, with each plant receiving $10 \mathrm{ml}$ of inoculum suspension. To ensure that the leaves were sufficiently wet, plants received water via aspersion in the afternoon three times a week.

\section{LATE BLIGHT SYMPTOMS EVALUATION}

Evaluation of resistance to $P$. infestans was performed for each of the four generations, including 20 plants of the female $\mathrm{P}_{\mathrm{S}}$ genitor (Santa Clara cultivar), 18 plants of the male $\mathrm{P}_{\mathrm{R}}$ genitor
(BGH 6902), $19 \mathrm{~F}_{1}$ hybrids, $281 \mathrm{~F}_{2}$ genotypes, 83 $\mathrm{BC}_{1: \mathrm{R}}$ genotypes, and $84 \mathrm{BC}_{1: \mathrm{S}}$ genotypes.

Leaves from each plant were scored according to the diagrammatic scale proposed by Corrêa et al. (2009) (Table I). Late blight severity scores were recorded for each leaf, every three days, in a total of six assessments. Overall score was the mean grade value for all the leaves on each plant.

These scores were used to determine the area under the disease progress curve (AUDPC) according to the estimator given by the following expression:

$$
\text { AUDPC }=\sum_{i=1}^{n=1}\left\{\left\lfloor\left(y_{i}+\frac{y_{i+1}}{2}\right)\right\rfloor *\left\lfloor t_{i+1}+t_{i}\right\rfloor\right\}
$$

Where: $y_{i}$ and $y_{\mathrm{i}+1}$ : percentage of lesioned leaf area observed in assessment $i$ and in the following assessment $\mathrm{i}+1 ; t_{i}$ and $t_{\mathrm{i}+1}$ : time interval between assessments; $n$ : number of assessments.

\section{STATISTICAL ANALYSIS}

Estimates of genetic parameters were based on the analysis of means proposed by Mather and Jinks (1984) and analyzed using the Genes program (Cruz 2013). Hypothesis tests related to the parameters were performed in the statistical software package Monogen version 0.1 (Silva 2003). This procedure involved the estimation and modeling of parameters related to the effect of a major gene and polygenes, based on the maximum likelihood method. Since

\section{TABLE I}

Late blight symptom severity classification scale proposed by Corrêa et al. (2009).

\begin{tabular}{cc}
\hline Classification & Disease severity \\
\hline 1 & $3 \%$ of the leaf lesioned \\
2 & $12 \%$ of the leaf lesioned \\
3 & $22 \%$ of the leaf lesioned \\
4 & $40 \%$ of the leaf lesioned \\
5 & $60 \%$ of the leaf lesioned \\
6 & $77 \%$ of the leaf lesioned \\
\hline
\end{tabular}


TABLE II

Genetic models for the resistance to $P$. infestans in tomato plants tested in this study.

\begin{tabular}{|c|c|}
\hline Models & Estimated parameters \\
\hline $\begin{array}{l}\text { 1: Major gene with } \\
\text { additive and dominance } \\
\text { effects }+ \text { polygenes with } \\
\text { additive and dominance } \\
\text { effects }\end{array}$ & $\mu, \mathrm{a}, \mathrm{d},[\mathrm{a}],[\mathrm{d}], \mathrm{Va}, \mathrm{Vd}, \mathrm{Sad}, \sigma^{2}$ \\
\hline $\begin{array}{l}\text { 2: Major gene with } \\
\text { additive and dominance } \\
\text { effects }+ \text { polygenes with } \\
\text { additive effect only }\end{array}$ & $\mu, \mathrm{a}, \mathrm{d},[\mathrm{a}], \mathrm{Va}, \sigma^{2}$ \\
\hline $\begin{array}{l}\text { 3: Major gene with } \\
\text { additive effect only }+ \\
\text { polygenes with additive } \\
\text { and dominance effects }\end{array}$ & $\mu, \mathrm{a},[\mathrm{a}],[\mathrm{d}], \mathrm{Va}, \mathrm{Vd}, \mathrm{Sad}, \sigma^{2}$ \\
\hline $\begin{array}{l}\text { 4: Major gene with } \\
\text { additive effect only }+ \\
\text { polygenes with additive } \\
\text { effect only }\end{array}$ & $\mu, \mathrm{a},[\mathrm{a}], \mathrm{Va}, \sigma^{2}$ \\
\hline $\begin{array}{l}\text { 5: Polygenes with } \\
\text { additive and dominance } \\
\text { effects }\end{array}$ & $\mu,[\mathrm{a}],[\mathrm{d}], \mathrm{Va}, \mathrm{Vd}, \mathrm{Sad}, \sigma^{2}$ \\
\hline $\begin{array}{l}\text { 6: Polygenes with } \\
\text { additive effect only }\end{array}$ & $\mu,[\mathrm{a}], \mathrm{Va}, \sigma^{2}$ \\
\hline $\begin{array}{l}\text { 7: Major gene with } \\
\text { additive and dominance } \\
\text { effects }\end{array}$ & $\mu, \mathrm{a}, \mathrm{d}, \sigma^{2}$ \\
\hline $\begin{array}{l}\text { 8: Major gene with } \\
\text { additive effect only }\end{array}$ & $\mu, \mathrm{a}, \sigma^{2}$ \\
\hline $\begin{array}{l}\text { 9: Environmental effects } \\
\text { only }\end{array}$ & $\mu, \sigma^{2}$ \\
\hline
\end{tabular}

the $\mathrm{P}_{\mathrm{R}}, \mathrm{P}_{\mathrm{S}}, \mathrm{F}_{1}, \mathrm{~F}_{2}, \mathrm{BC}_{1: \mathrm{R}}$ and $\mathrm{BC}_{1: \mathrm{S}}$ generations were evaluated, it was possible to estimate all the effects of the proposed models (Table II).

The function of maximum likelihood was used considering that the selected trait can be controlled by a major gene, with the variation observed between individuals due to the environment and minor-effect genes (Mood et al. 1974).

Maximum likelihood tests were performed using the Likelihood Ratio (LR) method (Mood et al. 1974) as follows:

$$
L R=-2 \ln \frac{L(M i)}{L(M j)}
$$

Where: $L(M i)$ and $L(M j)$ are the maximum likelihood functions of Models $i$ and $j$, respectively, and Model $i$ is hierarchical to Model $j$. Significance of Models was tested by Chi-square $\left(\chi^{2}\right)$ statistic method.

\section{RESULTS}

The mean late blight severity index of the $F_{1}$ generation exceeded the parental mean, indicating the presence of heterosis towards susceptibility (Table III). Since all $\mathrm{F}_{1}$ individuals (heterozygous at all loci) were more susceptible than those of $\mathrm{P}_{\mathrm{S}}, P$. infestans resistance observed in $\mathrm{P}_{\mathrm{R}}$ is likely controlled by recessive genes.

The component of environmental variance was smaller than the component of genetic variance, which means that genetic effects play a major role in phenotype manifestation (Table IV). Broad and narrow-sense heritability estimates were calculated at 53.19 and $13.09 \%$, respectively, indicating that the analyzed characteristic is highly influenced by the environment.

Major gene and/or polygene effects as well as the predominance of additive and dominant effects were estimated using the MLE method proposed by Silva (2003). This methodology involves pairwise comparisons (Table V) between the complete model (Model 1 from Table II) and each of the reduced models (Models 2 through 9). Significant results between pairwise Model comparisons indicate that the effect of the parameter present only in one of the models undergoing comparison is significant, and thus the complete model better explains the characteristic. On the other hand, a lack of significance indicates that the reduced model better explains the inheritance of resistance. The obtained results (Table $\mathrm{V}$ ) revealed that in the tested materials, $P$. infestans resistance is controlled by a major gene with additive and dominant effects, polygenes with an additive effect only, plus the environmental effect. For 
TABLE III

Means and amplitudes of late blight severity indices recorded with AUDPC for the $\mathrm{P}_{\mathrm{S}}, \mathrm{P}_{\mathrm{R}}, \mathrm{F}_{1}, \mathrm{~F}_{2}, \mathrm{BC}_{1: \mathrm{s}}, \mathrm{BC}_{1: \mathrm{R}}$ generations assessed in this study.

\begin{tabular}{ccc}
\hline Generations & Means & Amplitudes \\
\hline $\mathrm{P}_{\mathrm{S}}$ & 185.37 & $56.76-310.34$ \\
$\mathrm{P}_{\mathrm{R}}$ & 62.33 & $8.80-164.92$ \\
$\mathrm{~F}_{1}$ & 254.31 & $79.19-323.66$ \\
$\mathrm{~F}_{2}$ & 172.42 & $4.03-561.93$ \\
$\mathrm{BC}_{1: \mathrm{S}}$ & 239.22 & $8.40-390.14$ \\
$\mathrm{BC}_{1: \mathrm{R}}$ & 127.32 & $11.32-246.74$ \\
\hline
\end{tabular}

TABLE IV

Estimates of the parameters that influenced resistance to $P$. infestans assessed on the population $\left(\mathrm{F}_{2}\right)$ derived from the crossing between Solanum lycopersicum and Solanum habrochaites $f$. glabratum.

\begin{tabular}{cc}
\hline Parameters & $\mathbf{F}_{2}$ \\
\hline Phenotypic variance & 7917.92 \\
Genotypic variance & 3706.08 \\
Environmental variance & 4211.84 \\
Additive variance & 1036.49 \\
Dominance variance & 3175.36 \\
Broad-sense heritability & 53.19 \\
Narrow-sense heritability & 13.09 \\
Heterosis & 130.46 \\
\hline
\end{tabular}

TABLE V

Pairwise testing of the statistical models of inheritance of resistance to $P$. infestans in tomato plants assessed on the $P_{R}, P_{S}, F_{1}, F_{2}, B C_{1: R}, B_{1: S}$ generations derived from the crossing between Solanum lycopersicum and Solanum habrochaites $f$. glabratum using the function of maximum likelihood.

\begin{tabular}{ccc}
\hline Models & DF & $\boldsymbol{X}_{\mathbf{c}}$ \\
\hline 1 vs 2 & 3 & $4.8554^{\text {ns }}$ \\
2 vs 4 & 1 & $55.5231^{* *}$ \\
2 vs 7 & 2 & $43.7511^{* *}$ \\
2 vs 8 & 3 & $8.7484^{* *}$ \\
2 vs 9 & 4 & $126.8234^{* *}$ \\
\hline
\end{tabular}

${ }^{\text {ns }}$ not significant; ${ }^{* *}$ significant at $99 \%$ significance level by the Chi-square test. instance, the difference between Models 1 and 2, i.e., comparing the hypothesis of the existence of a major gene with additive and dominant effects and polygenes with additive and dominant effects, with that of the existence of a major gene with additive and dominant effects and polygenes with additive effects only, was not statistically significant, indicating that the dominant effects of polygenes do not affect the control of resistance to $P$. infestans. In contrast, the significant difference between models 2 and 4 confirms that a major gene with dominant effects is important in controlling this trait.

Similarly, significant differences were also recorded when comparing Models 2 and 7 , indicating the relevance of additive effects of polygenes, Models 2 and 8, indicating the importance of major gene additive effects, and Models 2 and 9, confirming the importance of environmental effects in the control of tomato plant response to $P$. infestans.

\section{DISCUSSION}

A better understanding of the inheritance of resistance to $P$. infestans in tomato plants is extremely important to correctly guide activities in breeding programs, and hence, achieve higher gains from selection. This study used a methodology that enables studying the inheritance of resistance to $P$. infestans in tomato plants through the identification of major genes and polygenes effects based on maximum likelihood estimators.

Differences in the late blight severity were observed between $\mathrm{P}_{\mathrm{S}}$ and $\mathrm{P}_{\mathrm{R}}$ genitors with an amplitude of 123.04 units of AUDPC, indicating that the $\mathrm{P}_{\mathrm{R}}$ genitor used is the source of $P$. infestans resistance genes in the materials. The higher mean disease severity index of the $\mathrm{F}_{1}$ generation suggests the presence of dominance towards susceptibility, making it difficult to produce hybrids resistant to $P$. infestans. Moreover, resistant phenotypes were observed only in homozygous individuals, which 
indicates that the genes responsible for resistance are recessive, reinforcing the results found by Elsayed et al. (2012).

Low estimates were obtained for both broad and narrow sense heritability in crosses between $S$. lycopersicum and $S$. habrochaites to $P$. infestans, similar to those recorded by Abreu et al. (2008). Low heritability is found particularly frequently in quantitative traits, typically highly influenced by environmental conditions (Ramalho et al. 1993, Abreu et al. 2008). Therefore, it is important to evaluate the extent of the genetic and environmental variation present in the breeding populations, since the variation caused by environmental conditions is temporary and cannot be used for selection purposes (Cruz 2012).

The significant differences found between Models 2 and 4, as well as between 2 and 8 suggest that the major gene responsible for resistance to $P$. infestans has additive and dominance effects, indicating that its inheritance is monogenic in nature. The higher mean found for the $\mathrm{F}_{1}$ generation in relation to its parents suggests the existence of a dominance effect, which also explains the reduction in the mean of the F2 generation. According to Gravina et al. (2004), dominance effects and genic interactions are less important to self-pollinating plants, since such effects act as perturbators in the soybean breeding programs whose purpose is to develop new plant lines. On the other hand, the presence of an additive component increases the likelihood of the resistance gene fixation in homozygous individuals from subsequent generations, providing higher gains from selection (Lobo et al. 2005).

Additive and dominance effects of a major gene have also been observed for other traits in tomato crops through the utilization of similar maximum likelihood estimation models. Gonçalves et al. (2007) determined that the inheritance of acylsugar content is controlled by a major gene with those effects, also suggesting a monogenic inheritance of this trait. The same methodology was also applied in studies involving bean and maize (Rezende et al. 2004, Batista et al. 2017), and provided wellsupported results regarding the determination of the gene effects controlling the characteristics studied therein.

The presence of a major gene indicates that resistance to $P$. infestans in tomato plants can be treated as a qualitative trait and therefore achieved through backcrossing. However, plants resistant to specific pathogen races due to main genes (vertical resistance) are resistant only at the beginning of the infection, a phenomenon resulting from the rapid development of more virulent isolates of the pathogen (Fry et al. 1993, Klarfeld et al. 2009). Race-specific resistance to $P$. infestans, however, is effective when multiple resistance genes are introgressed. Efforts towards gene pyramiding for race-specific resistance often results in more durable resistance, as has been observed in many plant species, including potato and tomato (Tan et al. 2010, Kim et al. 2012, Luo et al. 2012).

Whereas the lack of significance in the test comparing Models 1 and 2 indicates an absence of dominance effects in the polygenes, the significance of the test between Models 2 and 7 points to the polygenes with additive effects controlling the $P$. infestans resistance. Such resistance conferred by polygenes can be better understood via molecular analysis, which can be used to estimate the contributions of each polygene. Those polygenes can then be introgressed into new cultivars through programs of recurrent selection. Alternatively, marker-assisted selection is another effective strategy, since it can be very useful in gene pyramiding. This process guarantees the new cultivar long-term permanence on the market as it is more difficult for the pathogen to break a resistance conferred by multiple genes (Young and Kelly 1996).

A recent approach based on genome-wide association studies (GWAS) has been used to 
accelerate the rate of genetic gains in plant breeding programs. This technique aims to enhance genetic gains by a complete study of the plant genome (which is based on the identification of millions of SNP markers covering the whole genome extension) to predict genetic values of entire populations (Mosquera et al. 2016). Studies of this nature were recently performed for potato (Mosquera et al. 2016) barley (Gyawali et al. 2018) and rice (Spindel et al. 2016).

\section{CONCLUSIONS}

Resistance to $P$. infestans in tomato plants is a recessive trait, governed by a major gene with additive and dominant effects, polygenes with additive effects, plus the environmental effect.

Backcrossing can be used to introgress the major gene into tomato plants.

Recurrent and marker-assisted selection programs can be used to introgress the polygenes.

\section{ACKNOWLEDGMENTS}

The authors would like to acknowledge Departamento de Fitotecnia da Universidade Federal de Viçosa (UFV), and Conselho Nacional de Desenvolvimento Científico e Tecnológico (CNPq) for providing the MSc fellowship for first author.

\section{AUTHOR CONTRIBUTIONS}

Mariane Gonçalves Ferreira Copati, Flávia Maria Alves, Françoise Dalprá Dariva, Herika Paula Pessoa and Felipe de Oliveira Dias conducted the field trials, collected data, and wrote the manuscript. Pedro Crescêncio Souza Carneiro, Derly José Henriques da Silva and Carlos Nick helped on data analysis and reviewed the manuscript.

\section{REFERENCES}

ABREU FFB, SILVA DDJH DA, CRUZ CCD AND MIZUBUTI EESG. 2008. Inheritance of resistance to
Phytophthora infestans (Peronosporales, Pythiaceae) in a new source of resistance in tomato (Solanum sp.(formerly Lycopersicon sp.), Solanales, Solanaceae). Genet Mol Biol 31: 493-497.

BALDISSERA JNC, VALENTINI G, COAN MMD, GUIDOLIN AF AND COIMBRA JLM. 2014. Fatores genéticos relacionados com a herança em populações de plantas autógamas. Rev Ciênc Agrovet 13: 181-189.

BATISTA RO, SILVA LC, MOURA LM, SOUZA MH, CARNEIRO PCS, CARVALHO FILHO JLS AND DE SOUZA CARNEIRO JE. 2017. Inheritance of resistance to fusarium wilt in common bean. Euphytica 213: 133.

BURTON GW. 1951. Quantitative inheritance in pearl millet (Pennisetum glaucum). Agron Journal 43: 409-417.

CORREAA FM, BUENO FILHO JSS AND CARMO MGF. 2009. Comparison of three diagrammatic keys for the quantification of late blight in tomato leaves. Plant Pathol 58: 1028-1033.

CRUZ CD. 2012. Princípios de genética quantitativa. Universidade Federal de Viçosa, Viçosa, MG. n 576.5, 394 p.

CRUZ CD. 2013. GENES - Software para análise de dados em estatística experimental e em genética quantitativa. Acta Sci Agron 35: 271-276.

DUARTE H, ZAMBOLIM L AND WALDIR W. 2007. ARTIGOS Manejo da requeima do tomateiro industrial empregando sistema de previsão. Summa Phytopathol 33: 328-334.

ELSAYED AY, SILVA DJH DA, CARNEIRO PCS AND MIZUBUTI ESG. 2012. The inheritance of late blight resistance derived from Solanum habrochaites. Crop Breed Appl Biotechnol 12: 199-205.

FIORINI CVA, SILVA DJH, FONSECA F, MIZUBUTI ESG, ALVES DP AND DE SÁ CARDOSO T. 2010. Agrupamento de curvas de progresso de requeima, em tomateiro originado de cruzamento interespecífico. Pesqui Agropecuária Bras 45: 1095-1101.

FRY WE, GOODWIN SB, DYER AT, MATUSZAK JM, DRENTH A AND TOOLEY PW. 1993. Historical and Recent Migrations of Phytophthora-Infestans Chronology, Pathways, and Implications. Plant Disease 77: 653-661.

GONÇALVES LD, MALUF WR, CARDOSO MDG AND DO NASCIMENTO IR. 2007. Herança de acilaçúcares em genótipos de tomateiro provenientes de cruzamento interespecífico. Pesqui Agropecu Bras 42: 699-705.

GRAVINA GDA, MARTINS FILHO S, SEDIYAMA CS AND CRUZ CD. 2004. Parâmetros genéticos da resistência da soja a Cercospora sojina. Pesqui Agropecu Bras 39: 653659.

GYAWALI S, CHAO S, VAISH SS, SINGH SP, REHMAN S AND VISHWAKARMA SR. 2018. Genome wide association studies (GWAS) of spot blotch resistance at the seedling and the adult plant stages in a collection of spring barley. Mol Breed 38: 62.

KIM H-J, LEE H-R, JO K-R, MORTAZAVIAN SMM, HUIGEN DJ, EVENHUIS B, KESSEL G, VISSER RGF, 
JACOBSEN E AND VOSSEN JH. 2012. Broad spectrum late blight resistance in potato differential set plants MaR8 and MaR9 is conferred by multiple stacked R genes. Theor Appl Genet 124: 923-935.

KLARFELD S, RUBIN A AND COHEN Y. 2009. Pathogenic Fitness of Oosporic Progeny Isolates of Phytophthora infestans on Late-Blight-Resistant Tomato Lines. Plant Dis 93: 947-953.

LI Y, YANG L, PATHAK M, LI D, HE X AND WENG Y. 2011. Fine genetic mapping of cp: a recessive gene for compact (dwarf) plant architecture in cucumber, Cucumis sativus L. Theor Appl Genet 123: 973-983.

LOBO VLS, GIORDANO LDB AND LOPES CA. 2005. Herança da Resistência à Mancha-Bacteriana em Tomateiro. Fitopatol Bras 30: 343-349.

LUO Y, SANGHA JS, WANG S, LI Z, YANG J AND YIN Z. 2012. Marker-assisted breeding of Xa4, Xa21 and Xa27 in the restorer lines of hybrid rice for broad-spectrum and enhanced disease resistance to bacterial blight. Mol Breed 30: 1601-1610.

MATHER K AND JINKS JL. 1984. Introdução à Genética Biométrica. Sociedade Brasileira de Genética, Ribeirão Preto, $242 \mathrm{p}$.

MOOD AM, GRAYBILL FA AND BOES DC. 1974. Introduction to the theory of statistics, $3^{\text {rd }}$ ed., McGrawHill, New York, 405-406.

MOSQUERA T ET AL. 2016. Targeted and Untargeted Approaches Unravel Novel Candidate Genes and Diagnostic SNPs for Quantitative Resistance of the Potato (Solanum tuberosum L.) to Phytophthora infestans Causing the Late Blight Disease. PLoS ONE 11: 36.
PARK T-H, VLEESHOUWERS VGAA, HUTTEN RCB, VAN ECK HJ, VAN DER VOSSEN E, JACOBSEN E AND VISSER RG. 2005. High-resolution Mapping and Analysis of the Resistance Locus Rpi-abpt Against Phytophthora infestans in Potato. Mol Breed 16: 33-43.

RAMALHO M, SANTOS J AND ZIMMERMANN M. 1993. Genética Quantitativa em Plantas Autógamas: Aplicações ao Melhoramento do Feijoeiro. Editora UFG, Goiânia, Vol. 1, 271 p.

REZENDE VFVF, VENCOVSKY R, CÁRDENAS FENEN, SILVA HP, BEARZOTI E AND CAMARGO LEA. 2004. Mixed inheritance model for resistance to anthracnose leaf blight in maize. Crop Breed Appl Biotechnol 4: 115-122.

SILVA WP. 2003. Estimadores de máxima verossimilhança em misturas de densidade normais: uma aplicação em genética. 60f. Dissertação (Mestrado) - Universidade Federal de Lavras, Lavras, MG. (Unpublished).

SPINDEL JE, BEGUM H, AKDEMIR D, COLLARD B, REDOÑA E, JANNINK JL AND MCCOUCH S. 2016. Genome-wide prediction models that incorporate de novo GWAS are a powerful new tool for tropical rice improvement. Heredity (Edinb) 116: 395-408.

TAN MYA, HUTTEN RCB, VISSER RGF AND VAN ECK HJ. 2010. The effect of pyramiding Phytophthora infestans resistance genes $\mathrm{R} \mathrm{Pi-mcd1}$ and $\mathrm{R}$ Pi-ber in potato. Theor Appl Genet 121: 117-125.

YOUNG R AND KELLY J. 1996. Characterization of Genetic Resistence to Colletotrochum lindemuthianum in Common Bean Differential Cultivars. Plant Disease 80: 650-654. 